\title{
METODOLOGI ILMU EKONOMI ISLAM MONZER KAHF
}

\author{
Ahmad Ubaidillah \\ Fakultas Agama Islam Universitas Islam Lamongan \\ e-mail: ubaidmad@yahoo.com
}

\begin{abstract}
Science, including Islamic economics, is a systematic knowledge acquired in certain ways agreed upon by scientists. Certain ways to acquire such schematic knowledge are called methodologies. Science is obtained through investigation or investigation. But not every investigation can be called a legitimate and recognized way to gain the knowledge. Science has certain ways or processes called research. Thus, the methodology is in fact the ways or scientific research techniques. The technique here means ways of conducting an investigation and assessing the findings or evidences, ie judging whether the finds are true or false. After seeing how important the methodology is in building a discipline, especially the discipline of Islamic economics, this paper will try to answer the question: how is the methodology offered by Monzer Kahf to build Islamic economics? The research method used in this research concerns types, approaches, sources and data types, data collection techniques, data analysis techniques. The type of this research is library research, namely research conducted by taking and collecting data from the literature related to the issues discussed. Sources of research data obtained are from the existing literature, by collecting primary and secondary data. Primary data in this study refers to the books and other research journals by Monzer Kahf. The secondary data in this research is obtained from books, magazines, journals, articles, and so forth, written by other writer. Analytical technique used is descriptive-analytical analysis method. The results show that the task of describing the Islamic economic system consists of two parts. First, Islamic economists have to find the theory of the components of the economic system and its internal relations. Second, they are to investigate the economic validity and power of the system. Essentially, the approach used to find the Islamic economic system is similar to the approach used to find the general theories and rules of figh. Economics as one of the social sciences needs to develop a path to history to explore its experiences and determine the direction of long-term economic life. Islamic economists must revise conventional economic theory to recognize and separate biased postulates. In other words, refining theories is full of the dogmatic, doctrinal, and moral views of the experts and the environment.
\end{abstract}

Keywords: Islamic Economics, Methodology, Monzer Kahf

\section{Pendahuluan}

Memiliki sebuah metodologi yang sistematis dan teratur masih menjadi tantangan terbesar dalam membangun bangunan keilmuan ekonomi Islam. Ekonomi Islam sebagai sebuah bangunan ilmu (body of knowledge) tidak dapat dilahirkan tanpa sebuah metodologi ilmiah yang mantap. Metodologi ekonomi Islam dibangun berdasarkan worldview Islam yang melihat realitas ekonomi dalam perspektif yang komprehensif meliputi dimensi spiritual, material dan moral. Di samping itu, metodologi ekonomi Islam digali dari epistemologi Islam yang menggunakan sumber wahyu, akal dan pengalaman manusia sebagai sumber ilmu 
pengetahuan. Diskursus metodologi ekonomi Islam harus ditingkatkan dari sekedar memberikan perspektif islami terhadap teori dan bangunan ilmu ekonomi konvensional (sering disebut sebagai islamisasi ilmu pengetahuan), kepada sesuatu yang lebih genuine melahirkan teori dan mengembangkan bangunan ilmiah ekonomi Islam yang tersendiri. ${ }^{1}$

Sudah umum diketahui bahwa kegunaan mempelajari metodologi adalah untuk menyelidiki kebenaran teori, konsep, dan prinsip-prinsip suatu disiplin keilmuan. Dalam ilmu ekonomi konvensional, banyak sekali perbedaan pendapat mengenai metodologi. Ekonomekonom konvensional dari zaman klasik sampai sekarang masih membahas metodologi. Isuisu yang diangkat, di antaranya seputar ekonomi positif vs ekonomi normatif, metode induktif vs deduktif dan konsep nilai serta etika dalam perekonomian dan lain sebagainya.

Pertanyaan yang muncul adalah mengapa metodologinya perlu dipelajari untuk mengkaji suatu disiplin? Jawaban yang diberikan adalah metodologi yang dibutuhkan oleh kajian semua disiplin untuk mencapai kebenaran teori-teori yang terkandung dalam disiplin ilmu tersebut. Dalam bidang ekonomi, kita hanya perlu menemukan kebenaran tentang segala hal yang menyangkut teori ekonomi yang disajikan oleh orang yang bersangkutan dibandingkan dengan teori lainnya. Menurut perspektif ekonomi Islam, kecenderungan manusia untuk mencari kebenaran adalah dijelaskan oleh al-Quran. Al-Quran juga mendorong manusia untuk meninggalkan sesuatu yang ambigu dan berpegang pada kebenaran yang meyakinkan. $^{2}$

M. Husein Sawit dalam sebuah penelitiannya berjudul "Metodologi Penelitian Ekonomi Islam: Perlukah Berbedah?" memberikan kesimpulan bahwa para ahli ekonomi Islam perlu terus mengembangkan teori dan model-model ekonomi Islam. Model-model ini perlu diteliti kekuatan dan kelemahannya secara empiris, dan menarik sejumlah implikasi kebijakan sehingga mampu memberikan solusi altemalif terhadap masalah-masalah ekonomi mikro maupun makro. Untuk melaksanakan penelitian tersebut, peralatan yang telah ada atau sering digunakan dalam ekonomi konvensional tidak bertentangan dengan syariah sehingga tetap dapat dipakai dalam ekonomi Islam. Metodologi penelitian ilmiah tetap sama antara ekonomi konvensional dan ekonomi Islam. ${ }^{3}$

Ilmu pengetahuan, termasuk ilmu ekonomi Islam, adalah sebuah pengetahuan sistematis yang diperoleh dengan cara-cara tertentu yang telah disepakati oleh umat ilmuwan (al-ummah al- 'ālim). Cara-cara tertentu untuk memperoleh pengetahuan sisematis itu disebut metodologi. Ilmu pengetahuan diperoleh melalui investigasi atau penyelidikan. Namun tidak setiap penyelidikan dapat disebut cara yang sah dan diakui untuk memperoleh pengetahuan tersebut. Ilmu pengetahuan mempunyai cara-cara atau proses tertentu yang disebut penelitian (research). Dengan demikian, metodologi sebenarnya cara-cara atau "teknik penelitian ilmiah" (scientiric researh technique). Yang dimaksud teknik di sini adalah cara-cara

\footnotetext{
${ }^{1}$ Hafas Furqani, "Signifikansi Kajian Metodologi dalam Pengembangan Body of Knowledge Ekonomi Islam" dalam EQUILIBRIUM (Jurnal Ekonomi Syariah), Vol. 4, No.1 (Juni, 2016), 191-192.

2 Ahmad Maulidizen, "Methodology of Islamic economics: an Analysis Comparison" dalam Islamiconomic: Jurnal Ekonomi Islam, Vol. 8 No. 1 (2017), 2.

${ }^{3}$ M. Husein Sawit, "Metodologi Penelitian Ekonomi Islam: Perlukah Berbeda?" dalam JEP, Vol. 3 No. 1 (1998), 27.
} 
menjalankan investigasi dan menilai temuan-temuan atau bukti-bukti (evidences), yakni menilai apakah yang ditemukan tersebut benar (true) atau salah (false). ${ }^{4}$

Metodologi ilmu ekonomi Islam mempunyai pandangan-dunia (world views) tersendiri dan berangkat dari suatu ajaran moral agama, sehingga konsep kebenarannya pun berangkat dari sistem ajaran agama, yaitu Islam. Hal inilah yang membedakannya dengan metodologi ilmu ekonomi Barat (konvensional). Namun demikian, metodologi ilmu ekonomi Islam juga tidak sama sekali anti empirisme, mengingat ilmu ekonomi adalah bagian dari ilmu sosial yang bersifat praktis.

Oleh karena itu, metodologi ilmu ekonomi Islam dihadapkan kepada tiga sumber. Pertama, sumber ajaran agama. Kedua, sumber ilmu ekonomi konvensional. Ketiga, sumber data empiris. Tugas metodologi ilmu ekonomi Islam adalah bagaimana dapat mengintegrasikan ketiga sumber tersebut menjadi sebuah bangunan ilmu dan sistem ekonomi. $^{5}$

Setelah melihat betapa pentingnya metodologi dalam membangun suatu disiplin, terutama disiplin ekonomi Islam, tulisan ini akan mencoba menjawab pertanyaan: bagaimana metodologi yang ditawarkan oleh Monzer Kahf untuk membangun ilmu ekonomi Islam?

\section{Kajian Literatur}

Sudah banyak penelitian yang dilakukan dengan berbagai macamnya untuk mengungkap pemikiran ekonomi Islam Monzer Kahf. Namun, sebagian besar peneliti belum banyak yang menyentuh pemikiran Kahf tentang metodologi. Ada beberapa hasil penelitian yang perlu penulis tunjukkan. Di antaranya skripsi yang ditulis oleh Isyhar Malija Hakim yang berujudul "Analisis Komparatif Pemikiran Fahim Khan dan Monzer Kahf tentang Perilaku Konsumen”. Bagaimana pandangan Kahf tentang perilaku konsumen adalah salah satu pertanyaan yang hendak dijawab dalam penelitian tersebut. Jawabannya adalah bahwa menurut Monzer Kahf, ada dua faktor yang mempengaruhi perilaku konsumen, yaitu 1) faktor ekosogus; meliputi pendapatan, selera, teknologi, kesehatan lingkungan, kebudayaan, agama dan legalitas, dan 2) endogenus; meliputi informasi harga produk di pasar dan keberadaan barang subtitusi serta komplementer di pasar.

Kahf menyatakan bahwa rasionalisme Islam sebagai alternatif yang konsisten dengan nilai-nilai Islam. Faktor non-materialistik tidak dapat dipisahkan dari analisis terhadap perilaku konsumen dalam Islam. Unsur-unsur pokok dari rasionalisme Islam adalah konsep keberhasilan, egoisme dan altruisme, skala waktu perilaku konsumen, dan konsep harta. Harta dan pendapatan seorang Muslim akan dialokasikan ke dalam tiga keperluan, yakni konsumsi untuk kebajikan, untuk tabungan dan untuk konsumsi hidup. Dengan mengkombinasikan tiga keperluan tersebut secara seimbang dalam pemenuhannya sehingga dapat memaksimalkan fala $>h\}$.

Adapun barang-barang yang tidak memiliki manfaat dan kebaikan serta tidak membantu perbaikan secara material, moral dan spiritual bagi konsumennya seperti barang yang

\footnotetext{
${ }^{4}$ M. Dawam Rahardjo, "Metodologi Ekonomi Islam” dalam JEP, Vol. 3 No. 1 (1998), 3.

${ }^{5}$ Abdul Mughits, "Pengantar Epistemologi dan Metodologi Ilmu Ekonomi Islam" dalam Tim Penulis FSEI (ed), Filsafat Ekonomi Islam (Yogyakarta: Forum Studi Ekonomi Islam, 2008), 99.
} 
diharamkan zatnya atau karena cara memperolehnya yang $b a>t\} i l$, tidak dapat dianggap sebagai barang dalam Islam. Perbuatan untuk memanfaatkan/mengkonsumsi barang yang baik dianggap sebagai kebaikan bila diniatkan karena Allah SWT. Ajaran Islam menganjurkan perilaku konsumsi dan penggunaan harta secara wajar dan berimbang, yaitu pola perilaku konsumsi yang terletak di antara bakhïl dan isräf yang tak melampaui tingkat wajar. ${ }^{6}$

Penelitian kedua dilakukan oleh Irham Fahreza Anas yang berjudul "Analisis Komparatif Pemikiran Abdul Mannan dan Monzer Kahf dalam Konsumsi Islam”. Terkait pemikiran Kahf, Anas mengajukan pertanyaan: bagaimana pemikiran Kahf tentang konsumsi dalam perspektif ekonomi Islam? Hasil penelitian menunjukkan bahwa rasionalisme Islam dinyatakan sebagai alternatif yang konsisten dengan nilai-nilai Islam. Barang-barang yang tidak memiliki kebaikan dan membantu meningkatkan manusia bukanlah barang dan tidak dapat dianggap sebagai aset atau milik umat Islam. Oleh sebab itu, barang-barang yang dilarang tidak dianggap barang dalam Islam. ${ }^{7}$

Ada beberapa buku yang membahas pemikiran Kahf, namun buku-buku tersebut tidak menjabarkan pemikirannya tentang metodologi. Di antaranya adalah buku yang ditulis oleh Muhammad Aslam Haneef yang berjudul Pemikiran Ekonomi Islam Kontemporer: Analisis Komparatif Terpilih yang diterjemahkan oleh Suherman Rosyidi. Buku yang ditulis oleh Nur Chamid dengan judul Jejak Langkah dan Sejarah Pemikiran Ekonomi Islam. Dan karya yang ditulis oleh Havis Aravik dengan judul Sejarah Pemikiran Ekonomi Islam Kontemporer.

Itulah beberapa hasil penelitian dan buku yang berhasil penulis cantumkan sebagai kajian pustaka dalam meneliti pemikiran Kahf. Sepanjang pengetahuan penulis, belum ada karya dengan berbagai jenisnya, yang secara khusus mengkaji pemikiran metodologi ilmu ekonomi Islam Kahf, baik dalam bahasa kita maupun bahasa asing.

\section{Metode Penelitian}

Metode penelitian yang digunakan dalam penelitian ini menyangkut jenis, pendekatan, sumber dan jenis data, teknik pengumpulan data, teknik analisis data. Adapun jenis penelitian ini adalah penelitian kepustakaan (library research), yaitu penelitian yang dilakukan dengan cara mengambil dan mengumpulkan data dari literatur yang berhubungan dengan masalah yang dibahas. Dengan segala usaha yang dilakukan oleh penulis untuk menghimpun informasi yang relevan dengan topik atau masalah yang akan diteliti. Informasi tersebut dapat diperoleh dari buku-buku ilmiah, laporan penelitian, karangan-karangan ilmiah, ensiklopedia serta sumber-sumber tertulis.

Sumber data penelitian yang diperoleh adalah dari literatur-literatur yang ada, dengan cara pengumpulan data primer dan sekunder. Data Primer merupakan data yang diperoleh langsung dari sumbernya atau objek penelitian. Data primer pada penelitian ini merujuk pada buku-buku maupun jurnal-jurnal penelitian lainnya karya Monzer Kahf. Sedangkan untuk data sekunder, yaitu data yang sudah diterbitkan atau digunakan oleh pihak lain. Seperti, majalah, makalah atau karya ilmiah, koran dan lain sebagainya. Pada data sekunder ini,

\footnotetext{
${ }^{6}$ Isyhar Malija Hakim, "Analisis Komparatif Pemikiran Fahim Khan dan Monzer Kahf Tentang Perilaku Konsumen” (Skripsi--UIN Walisongo, Semarang, 2015), 165-167.

${ }^{7}$ Irham Fahreza Anas, "Analisis Komparatif Pemikiran Abdul Mannan dan Monzer Kahf dalam Konsumsi Islam” (Skripsi--UIN Syarif Hidayatullah, Jakarta, 2008), 135.
} 
literatur lainnya yang relevan dengan permasalahan yang akan dikaji pada penelitian ini, seperti buku, majalah, jurnal, artikel, dan lain sebagainya.

Setelah data terkumpul kemudian dianalisis dengan menggunakan teknik analisis data kualitatif, yaitu data yang tidak bisa diukur atau dinilai dengan angka secara langsung. Karena itu penelitian ini menggunakan metode analisis deskriptif-analitis. Yaitu merupakan metode yang berupaya menjabarkan gambaran-gambaran umum dan menganalisis secara kritis pemikiran Monzer Kahf perihal metodologi ekonomi Islam.

\section{Biografi dan Karya-karya Monzer Kahf}

Monzer Kahf dilahirkan di Damaskus, Syria, pada tahun 1940. Kahf adalah orang pertama yang mencoba mengaktualisasikan penggunaan institusi distribusi Islam (zakat, sedekah) terhadap agregat ekonomi, pendapatan konsumsi, konsumsi, simpanan dan investasi. Beliau menerima gelar B.A. di bidang Bisnis dari Universitas Damaskus pada tahun 1962 serta memperoleh penghargaan langsung dari Presiden Syria sebagai lulusan terbaik. Pada tahun 1975, Kahf meraih gelar Ph.D untuk ilmu ekonomi spesialisasi ekonomi internasional dari University of Utah, Salt Lake City, Amerika Serikat. Selain itu, Kahf juga pernah mengikuti kuliah informal, yaitu Training and Knowledge of Islamic Jurisprudence (Fiqh) and Islamic Studies di Syria. Sejak tahun 1968, beliau telah menjadi akuntan publik yang bersertifikat. Pada tahun 2005, Kahf menjadi guru besar ekonomi Islam dan perbankan di The Graduate Program of Islamic Economics and Banking, pada Universitas Yarmouk, Yordania.

Lebih dari 34 tahun Monzer Kahf mengabdikan dirinya di bidang pendidikan. Ia pernah menjadi asisten dosen di Fakulas Ekonomi University of Utah, Salt lake City (1971-1975). Beliau juga pernah aktif sebagai instruktur di School of Bussiness, University of Damascus, Syria (1962-1963). Pada 1984, Kahf memutuskan untuk bergabung dengan Islamic Development Bank (IDB) dan sejak 1995 ia menjadi ahli ekonomi Islam senior di IDB. ${ }^{8}$ Kahf berkeliling di komunitas Muslim di Amerika Utara dan luar negeri serta memberikan kuliah tentang berbagai persolaan masyarakat, khususnya bidang ekonomi dan keuangan. Dia memberi kuliah dalam bentuk konferensi, seminar, dan perkumpulan tentang teori dan praktik keuangan Islam di Amerika Utara dan negara-negara lain di dunia mengenai ekonomi dan perbankan Islam, wakaf, akad-akad syariah, perencanaan tanah, zakat, khutbah jumat di masjid dan pusat-pusat Islam. ${ }^{9}$

Pada tahun 1984, Kahf memutuskan untuk bergabung dengan Islamic Development Bank (IDB) dan sejak 1995 beliau menjadi ahli ekonomi Islam senior di IDB. Pada tahun 1978, Kahf menerbitkan buku tentang ekonomi Islam yang berjudul "The Islamic Economy: Analytical Study of the Functioning of the Islamic Economic System”. Buku ini dianggap sebagai awal dari sebuah analisis matematika ekonomi dalam mempelajari ekonomi Islam, karena pada tahun 1970-an, sebagian besar karya mengenai ekonomi Islam masih mendiskusikan soal prinsip dan garis besar ekonomi.

\footnotetext{
${ }^{8}$ Havis Aravik, Sejarah Pemikiran Ekonomi Islam Kontemporer (Jakarta: Kencana, 2017), 63.

${ }^{9}$ Monzer Kahf, "Islamic Economics: Notes on Definitionand Methodology" dalam Sercan Karadoğan (ed), Islamic Economics: On Definition and Methodology (Istambul: Alioğlu Printing, 2014), 30.
} 
Adapun hasil karya Monzer Kahf yang lain adalah A Contribution to the Theory of Consumer Behavior in an Islmaic Society, Kairo, Mesir, 1984. "Principles of Islamic Financing: A Survey", diterbitkan atas kerja sama dengan Islamic Development Bank (IDB), 1992 (Ditulis bersama Taqiullah). Zakah Management in Some Muslim Societies, diterbitkan atas kerja sama dengan Islamic Development Bank (IDB), 1993. "The Calculating of Zakah for Muslim in North America", Indiana, USA, 1996. Financing Development in Islam yang diterbitkan atas kerja sama dengan Islamic Development Bank (IDB), 1996. Serta, beberapa artikel dan paper lainnya yang tidak dapat disebutkan seluruhnya di sini. ${ }^{10}$

Di akhir tahun tujuh puluhan dan awal delapan puluhan, buku Kahf yang berjudul The Islamic Economy: Analytical Study of the Functioning of the Islamic Economic System merupakan salah satu dari sedikit contoh literatur ekonomi Islam kontemporer dan dibaca dengan seksama oleh para mahasiswa di banyak universitas yang menawarkan mata kuliah ekonomi Islam. Buku tersebut juga telah diterjemahkan ke dalam bahasa Malaysia dan selalu digunakan sebagai buku teks ekonomi Islam di banyak universitas Malaysia. Dewasa ini, Kahf adalah Senior Researcher di The Islamic Research and Training Institute pada Islamic Development Bank, Jeddah. ${ }^{11}$

\section{Metodologi Monzer Kahf}

Sebelum menjelaskan metodologi dan alat yang digunakan Kahf dalam membangun keilmuan ekonomi Islam, perlunya kiranya membeberkan definsi ekonomi Islam yang digagasnya. Kahf memberikan definisi ekonomi Islam sebagai "kajian perilaku ekonomi manusia laki-laki dan wanita, baik sebagai pelaku individual, komunal, maupun kesatuan kolektif'. Perbedaan definisi di kalangan ekonom muslim akan berdampak pada metodologinya. Kahf menyadari bahwa tidak ada kesepakatan di antara ekonom muslim terkait definisi ekonomi Islam, cakupan, hubungannya dengan ekonomi konvensional, metode, dan alat analisis, bahkan beberapa asumsi dasarnya. ${ }^{12}$ Kecenderungan mempertahankan perbedaan antara ekonomi Islam dan konvensional membuat beberapa ekonom muslim percaya bahwa ekonomi Islam merupakan disiplin yang mandiri, bebas dari ekonomi konvensional.

Di tempat lain, Kahf mendefinisikan ekonomi Islam sebagai perilaku manusia, dalam segala aspeknya, dipandu oleh sejumlah nilai agama dan moral Islam, baik di bidang hukum, politik dan sosial. ${ }^{13}$ Kahf mencatat beberapa hal penting terkait apakah ekonom muslim perlu menciptakan ekonomi alternatif dalam bentuk ekonomi Islam, ataukah kita secara sederhana memiliki perspektif Islam tentang ekonomi.

Pertama, ada kebutuhan mengembangkan suatu disiplin yang mengkaji persoalanpersoalan yang biasanya dijelaskan sebagai pokok persoalan ekonomi dalam landasan universal. Kedua, tidak ada kebutuhan untuk menambahkan kata sifat, "islami" terhadap disiplin ekonomi. Penambahan semacam ini tidak diperlukan oleh agama Islam, dan para

\footnotetext{
${ }^{10}$ Havis Aravik, Sejarah Pemikiran Ekonomi Islam Kontemporer, 64.

11 Mohamed Aslam Haneef, Pemikiran Ekonomi Islam Kontemporer: Analisis Komparatif Terpilih, terj. Seherman Rosyidi (Jakarta: PT Raja Grafindo Persada, 2010), 87-88.

12 Monzer Kahf, "Islamic Economics: Notes on Definition and Methodology" dalam Review of Islamic Economics, No. 13 (2003), 31.

${ }^{13}$ Ibid., 31.
} 
sarjana muslim tidak melakukannya ketika memimpin peradaban. Penambahan tersebut juga menyesatkan karena menunjukkan bahwa "hukum" ekonomi Islam tidak bersifat universal dan umum bagi semua manusia. Lebih jauh, tambahan "islami" pada ekonomi dapat bersifat membatasi, khususnya ketika kata islami mengurangi cakupan disiplin dalam kerangka postulat yang mengandung nilai-nilai Islam. Ketiga, tragedi peristiwa sejarah yang mengharuskan umat Islam gagal keluar dari peradaban manusia selama beberapa abad terakhir, yang diikuti oleh keterkungkungan ilmu ekonomi dengan sinaran budaya YahudiRoma. Keempat, mengkaji sistem ekonomi Islam harus memasukkan "apa yang seharusnya” dan dampaknya terhadap variabel dan hubungannya dalam perekonomian Islam. Dampak ini harus dianalisis dalam sinaran teori ekonomi yang universal dan humanistis, bebas dari prakonsepsi. Kelima, istilah ekonomi Islam dibenarkan secara longgar sebagai sub cabang dari ilmu ekonomi konvensional yang membahas sistem ekonomi Islam dan dampaknya terhadap variabel dan keputusan ekonomi. ${ }^{14}$

Jika ekonomi Islam secara luas dianggap sebagai bagian dari ilmu ekonomi modern (konvensional), ekonomi Islam tidak lebih dari penerapan teori ekonomi pada persoalan sistem ekonomi Islam. Ekonomi Islam bukanlah ilmu pada dirinya sendiri, dan tidak menyingkirkan karakteristik ilmiah ilmu ekonomi modern. Sementara itu, teori ekonomi Barat (konvensional), menurut Kahf, dikarenakan alasan historis yang memasukkan prakonsepsi dan asumsi Yahudi-Roma, gagal menjelaskan persoalan manusia, terutama kurangnya kebijksanaan yang digali dari wahyu. Proposisi ilmu ekonomi modern dipengaruhi oleh sistem nilai dan ideologi lokal. Kahf menyadari bahwa ada perbedaan antara ekonom Islam (islamic economists) dan ekonom konvensional (conventional economists) terkait sistem nilai yang dipegangnya meskipun seringkali disembunyikan. Ilmu-ilmu sosial, termasuk ilmu ekonomi, pertautan antara ekonom dan nilai-nilai sosial, personal, dan ideologis, tidak dapat dipisahkan. Ekonom Islam, karena kesadaran ideologisnya, biasanya lebih jelas tentang pertautan ideologis daripada ekonom konvensional.

Karena alasan tersebut, Kahf menetapkan tugas yang harus dilakukan oleh para pegiat ekonomi Islam. Pertama, mengembangkan sistem ekonomi Islam. Kedua, merevisi teori ekonomi konvensional.

Sistem ekonomi, menurut Kahf terdiri dari tiga komponen, yaitu ideologi atau filsafat dasar, seperangkat aksioma, asumsi, dan prinsip-prinsip umum, yang digali dari ideologinya. Aturan-aturan yang bersifat operasional, ketika diterapkan ke dalam sumber daya alam dan manusia, berakibat pada perumusan dan pembentukan hubungan produksi, distribusi, dan konsumsi dan juga tingkat prestasi ekonomi masyarakat. Oleh karena itu, lanjut Kahf, sistem ekonomi harus bersentuhan dengan kehidupan nyata, sama dengan sistem hukum yang harus menjaga implementasinya jika ingin tetap bertahan. ${ }^{15}$

Oleh karena alasan tersebut, Kahf menunjukan tugas bagi ekonom Islam untuk mengembangkan sistem ekonom Islam yang terdiri dari dua bagian. Pertama, melakukan penemuan teoretis semua komponen sistem dan hubungan internalnya. Kedua, pengujian validitas ekonomi dan penerapan sistem yang menyangkut keterpengaruhan variabel dan

\footnotetext{
${ }^{14}$ Monzer Kahf, "Islamic Economics”, 31-32.

15 Ibid., 33.
} 
perilaku dalam kerangkanya. Menurut Kahf, al-Quran dan Sunnah sebagai sumber utama Islam hanya menyediakan garis besar sistem ekonomi Islam dan banyak bahan yang harus diolah oleh pemikir-pemikir muslim. Meskipun banyak persoalan yang telah disebutkan dalam al-Quran dan Sunnah, masih banyak kesempatan untuk berupaya menemukan kandungan dan prinsip-prinsip ekonomi yang dijelaskan oleh Allah dan Rasul-Nya. Kahf berpendapat bahwa pendekatan untuk mengembangkan sistem ekonomi Islam sama dengan menemukan teori dan aturan umum fikih. Dalam merumuskan teori dan aturan umum fikih, para ahli fikih harus mensurvey semua teks al-Quran dan Sunnah.

Beberapa teori mungkin diambil secara langsung dari teks-teks al-Quran dan Sunnah, mislanya larangan riba dan kewajiban zakat. Dalam kasus yang lain, prinsip atau teori dapat diambil dengan meneliti beberapa teks mengungkapkan kecenderungan atau membuat teori umum, misalnya pilihan distribusi pendapatan yang pantas. Teori dapat juga berdasarkan rasionalitas dan akal sehat, misalnya mempertimbangkan kemajuan ummah sebagai tujuan utama sistem ekonomi Islam, rencana dan keputusan pemerintah. Prinsip-prinsip asumsi, aksioma dan teori yang telah ditemukan diikuti oleh langkah kedua yang merupakan penelitian validitas ekonominya dalam kehidupan nyata. Bukti empiris akan menujukkan pengujian valid sebagai dasar-dasar sistem ekonomi Islam untuk memberikan proses umpan balik dalam berjalannya aturan sistem opersional.

Ekonom-ekonom Islam juga perlu melakukan tugas kedua, yaitu merevisi teori ekonomi konvensional. Tugas ini menyangkut dua langkah. Pertama, takhliyah, yaitu mengidentifikasi dan menyingkirkan postulat-postulat bias yang melekat pada dogma, pandangan dogmatis, moral atau doktrinal ekonomi konvensional. Kedua, tahliyat, yakni penggabungan ilmu ekonomi dan postulat-postulat positif yang berasal dari syariah. Akan tetapi, Kahf mengingatkan, membedakan premis dan alat di mana ekonom Islam melihat ekonomi Islam yang memiliki perselisihan kecil dengan alat analisis ekonomi konvensional sangat penting. ${ }^{16}$ Untuk lebih jelas, penulis akan menguraikan metodologi ilmu ekonomi Islam yang digagas Kahf bertikut ini.

\section{Menguraikan Sistem Ekonomi Islam}

Setiap sistem ekonomi pasti didasarkan atas ideologi yang memberikan landasan dan tujuannya, di satu pihak, dan aksioma-aksioma serta prinsip-prinsipnya, di lain pihak. Proses yang diikuti dengan seperangkat aksioma dan prinsip, dimaksudkan untuk lebih mendekatkan tujuan sistem tersebut, merupakan landasan dari sistem tersebut yang bisa diuji. Setiap sistem ekonomi membuat kerangka di mana suatu komunitas sosio-ekonomi dapat memanfaatkan sumber-sumber alam dan manusia untuk kepentingan produksi dan mendistribusikan hasilhasil produksi ini untuk kepentingan manusia. Suatu sistem yang mendukung ekonomi Islam harus diformulasikan berdasarkan pandangan Islam tentang kehidupan. Berbagai aksioma dan prinsip dalam sistem seperti itu seharusnya ditentukan secara pasti dan proses

\footnotetext{
${ }^{16}$ Mohamed Aslam Haneef dan Hafas Furqani, "Methodologi of Islamic economics: Overview of Present State dan Future Direction" dalam International Journal of Economics, Management \& Accounting, Vol. 19, No. 1 (2011), 12-13.
} 
fungsionalisasinya seharsunya dijelaskan agar dapat menunjukkan kemurnian dan aplikabilitasnya. ${ }^{17}$

Tugas untuk menguraikan sistem ekonomi Islam terdiri dari dua bagian. Pertama, menemukan teori komponen sistem ekonomi dan hubungan internalnya. Kedua, menyelidiki validitas ekonomi dan daya terap sistem tersebut. Secara esensial, sebagaimana yang sudah penulis singgung di atas, pendekatan yang digunakan untuk menemukan sistem ekonomi Islam sama dengan pendekatan yang digunakan untuk menemukan teori dan aturan umum fikih. Dalam merumuskan teori-teori dan aturan umum fikih, para fuqahä' harus menyelidiki semua teks-teks al-Quran dan Sunnah. Beberapa teks mungkin secara langsung bisa diambil dari teks-teks itu sendiri. ${ }^{18}$

Selain itu, perlu diperhatikan bahwa metodologi uṣūl sangat tergantung pada logika metematika. Prinsip analogi (qiyās) hanyalah aplikasi prinsip-prinsip persamaan matematika, penambahan, dan lain sebaginya. Analogi, dalam berbagai macamnya, terdiri dari menemukan kesamaan dan perbedaam antara sesuatu dengan aturan-aturan syariah yang sudah dikenal, dan hal lain yang aturannya ditentukan dan mengambil yang terakhir dari yang pertama menurut kesamaan dan perbedaan. Analogi alat sangat diperlukan untuk menemukan sistem ekonomi Islam. Sementara metodologi uṣūl beroperasi pada teks-teks sumber-sumber Islam. Ekonom Islam, dalam menggunakan upayanya menemukan sistem ekonom Islam bekerja dengan teks-teks fikih. Dengan kata lain, fikih merupakan sumber pengetahuan yang sangat penting bagi ekonom Islam. Misalnya dalam mengembangkan instrumen keuangan yang sesuai dengan syariah, pemahaman yang mendalam posisi fikih tentang muḍārabah, kerjasama, kontrak penjualan, peminjaman, dan ribä, sangatlah penting. ${ }^{19}$

Di sini dapat disimpulkan bahwa metodologi menarik sistem ekonomi Islam dari sumber dasar Islam sama dengan metodologi mengembangkan aturan dan teori umum fikih. Memanfaatkan sepenuhnya teks-teks al-Quran dan Sunnah untuk menarik "bentuk" umum atau pilar dasar sistem ekonomi Islam dan menyesuaikan kasus individual dengan pilar-pilar ini, sementara pada saat yang sama, mengambil warisan fikih sebagai alat yang berguna untuk memahami teks-teks tersebut.

Lebih jauh dapat dikatakan, ada kesamaan antara penggunaan ijtihad yang digunakan untuk menguraikan sistem ekonomi Islam dan ijtihad yang digunakan untuk menarik sistem fikih Islam. Ada juga kesamaan dalam alat untuk menguji daya terapnya (apllicability). Aplikasi dalam kehidupan nyata dan data empiris menggambarkan pengujian sesungguhnya untuk keperluan validitas sistem ekonomi Islam. Mereka juga memberikan dasar untuk proses umpan balik yang diperlukan dalam berjalannya aturan operasional sistem. Kahf mencontohkan zakat yang berdasarkan pada doktrin keadilan dan kelemahan sistem pasar untuk mencapai keadilan distributif. Prinsip umum zakat digali dari teks-teks al-Quran dan Sunnah. Prinsip-prinsip ini meliputi item-item utama yang terkena zakat dan klasifikasi kategori yang berhak menerima zakat. $^{20}$

\footnotetext{
${ }^{17}$ Monzer Kahf, "Islamic Economics and Its Methodology" dalam Syed Omar Syed Agil dan Aidit Ghazali (ed), Reading in the Concept and Methodology of Islamic Economics (Malaysia: CERT Publication, 2007), 53.

${ }^{18}$ Monzer Kahf, "Islamic Economics", 34.

${ }^{19}$ Ibid., 35.

${ }^{20}$ Ibid., 36 .
} 
Kahf memandang penting studi sejarah untuk memahami ilmu ekonomi karena sejarah adalah laboratorium ilmu pengetahuan umat manusia. Ekonomi sebagai salah satu ilmu sosial perlu mengembangkan jalan ke arah sejarah untuk menggali pengalamannya dan menentukan arah kehidupan ekonomi jangka panjang. Kajian historis dalam ilmu ekonomi paling tidak mencakup dua aspek yang sangat penting, yaitu sejarah pemikiran ekonomi dan sejarah kesatuan ekonomi misalnya individu, perusahaan, masyarakat, dan sebagainya. Sayang sekali, menurut Kahf, ekonom-ekonom muslim sedikit sekali atau masih kurang memberikan perhatian pada sejarah pemikiran ekonomi Islam. Ini tentu saja sangat disayangkan, karena melalui sejarah pemikiran ekonomi muslim, kita dapat memahami gagasan-gagasan ekonominya. Padahal dari sana kita bisa melihat pendiri sesungguhnya ilmu ekonomi Islam.

Oleh karena itu, sangat perlu melakukan penelitian untuk pemikiran ekonomi pemikirpemikir besar muslim, misalnya Abū Yūsuf, Yahyā ibn Ādam, al-Ghazāli, Ibn Rushd, al-'Izz ibn Abd Salām, al-Farabi, Ibn Taimiyyah, al-Maqrizi, Ibn Khaldun, dan lain sebagainya. Kita tidak cukup hanya mengembangkan atau mengambil begitu saja pemikiran-pemikiran ekonomi intelektual-intelektual muslim tersebut tanpa memahami metode berpikir kiritis mereka. Di sinilah pentingnya tidak hanya berpikir normatif, tetapi juga berpikir historis.

Pengkajian sejarah perkembangan ekonomi Islam, bagi Kahf, akan memberikan pengujian empiris yang dibutuhkan untuk gagasan-gagasan ekonomi sekarang dan masa depan. Oleh karena itu, penyelidikan historis menjadi sangat penting, khususnya pada bidang kebijakan ekonomi dan keuangan publik. Namun, perlu kiranya diwaspadai ketika kita mengkaji aspek historis Islam ini, sebagaimana yang dicatat oleh Kahf. Pertama, bahaya kekeliruan mencocokkan teori dengan aplikasinya. Kedua, bahaya membatasi teori dengan sejarahnya.

Bahaya pertama muncul ketika pemikir-pemikir ekonomi muslim modern tidak membedakan secara jelas antara konsepsi Islam dan penerapan historisnya. Ini sering kali terjadi pada bidang keuangan publik. Hampir semua karya tentang keuangan publik yang ada di perpustakaan Islam kontemporer menganggap sumber daya negara sudah ada pada masa kejayaan Islam, dari Umar ibn Khațāab hingga Hārun al-Rashìd. Sangat sedikit perhatian yang diberikan pada pengembangan teori keuangan publik berdasarkan pada al-Quran dan Hadis Nabi Muhammad SAW. Akhirnya, ini berakibat pada penyajian historis keuangan publik dalam Islam yang miskin pengujian aplikasinya pada saat ini dikarenakan kurangnya kesempatan di negara-negara muslim.

Bahaya kedua muncul ketika ekonom-ekonom muslim menganggap pengalaman historis sebagai pedoman atau rujukan mengikat pada saat ini. Ini berakibat pada ketidakmampuan memahami al-Quran dan Sunnah secara langsung, yang pada gilirannya menciptakan teori ekonomi Islam yang hanya bersifat historis ketimbang ideologis. Pendekatan historis untuk pengkajian ekonomi Islam terkadang diterapkan dengan mengacu pada keadaan masyakat muslim saat ini. Ini berimplikasi pada ilmu ekonomi Islam yang lebih membahas persoalan-persoalan keterbelakangan, misdistribusi kekayaan dan pendapatan, perilaku konsumsi yang kurang tepat, dan lain sebagainya ketimbang mengkaji mekanisme makro ekonomi sistem ekonomi Islam. ${ }^{21}$

\footnotetext{
${ }^{21}$ Monzer Kahf, "Islamic Economics and Its Methodology”, 54-56.
} 


\section{Merevisi Teori Ekonomi Konvensional}

Tugas kedua yang harus dilakukan oleh ekonom-ekonom Islam adalah merevisi teori ekonomi konvensional untuk mengenali dan memisahkan postulat-postulat yang bias. Dengan kata lain, memperbaiki teori-teori yang penuh dengan pandangan dogmatis, doktrinal, dan moral para ahlinya dan lingkungan sekitar. Meskipun hukum-hukum ekonomi itu bersifat universal, namun ketika menemukan hukum-hukum tersebut sebagai proses yang dipengaruhi oleh gagasan dan nilai-nilai para peneliti dan perilaku sosial yang ada dan etika moral dari entitas sosial yang perilakunya ditinjau oleh para ahli disiplin tersebut. Ditambahkan bahwa mengenali dan memisahkan dampak tindakan-tindakan yang penuh dengan nilai tersebut bukanlah tugas yang mudah dalam ilmu-ilmu sosial manapun, tidak hanya ilmu ekonomi, dikarenakan sifat alamiah fenomena sosial dan karakteristiknya dibandingkan dengan fenomena fisik. Dalam postulat ilmu ekonomi, nilai-nilai dan gagasan bercampur baur dengan penelitian objektif, dalam taraf tertentu, banyak data dari displin ini bercampur dengan pernyataan normatif dan positif. ${ }^{22}$

Akan tetapi, kerumitan tugas memurnikan ilmu ekonomi konvensional dari peryimbangan nilai yang berasal dari gagasan-ggaasan, keyakinan, nilai-nilai para ahlinya dan lingkungan sekitarnya mungkin mengharuskan kita berhenti membuat pra-asumsi yang jelas ketimbang menghilangkan semuanya. Bagian lain tugas ekonom-ekonom Islam yang juga tidak mudah dan sederhana adalah penggabungan postulat-postulat positif dalam ekonomi konvensional yang digali dari syariah. ${ }^{23}$

Dalam menjalankan fungsi takhliyat (mengeluarkan yang tidak benar) dan tahlliyat (menambahkan yang baik), perbedaaan jelas antara premis dan alat juga sangat diperlukan. Ekonom-ekonom Islam memiliki sedikit perselisihan dengan ekonomi konvensional. Pentingnya logika matematika dan data empiris sebagai alat analisis bagi semua ekonom, baik Islam maupun Barat, yang diingat-ingat bahwa proses memperbaiki disiplin akan memerlukan perubahan penekanan dan kadang-kadang rumusan berbeda untuk persoalan tententu, namun perbaikan alat analisis semacam ini merupakan proses alamiah dan berkelanjutan dalam ilmu ekonomi dan tidak membenarkan klaim metodologi yang berbeda. Ini mungkin tidak menyenangkan beberapa ekonom-ekonom Islam yang lebih menyukai menunjukkan disiplin ekonomi Islam yang memiliki independensi dari ekonomi konvensional. Dalam melakukan itu, mereka berkencenderungan menolak instrumen-intrumen analisis ekonomi dan menginginkan yang berbeda. Pada sebagian ekonom muslim, ini mungkin akan menjadi aksioma yang membingungkan untuk metodologi. ${ }^{24}$

Dalam upaya untuk membersihkan ilmu ekonomi konvensional dari peryimbangan nilai yang dimasukkan oleh ekonom-ekonom Barat dan memperkaya ekonomi konvensional dengan aksioma-aksioma bebas nilai yang digali dari wahyu sebagai sumber utama pengetahuan manusia, ekonom-ekonom Islam barangkali harus mendefinisikan kembali dan menyaring beberapa konsep utama teori ekonomi, namun mereka tidak perlu membuang metodologi induktif dan alat analisis dalam kerangka ideologis. ${ }^{25}$

\footnotetext{
${ }^{22}$ Monzer Kahf, "Islamic Economics", 37.

${ }^{23}$ Ibid., 38.

${ }^{24}$ Ibid., 38-39.

${ }^{25}$ Ibid., 40.
} 
Kahf memberikan cacatan kepada kita semua bahwa kontroversi metodologis dalam teori ekonomi belum berakhir. Oleh sebab itu, ekonom-ekonom Islam, sudah sepantasnya menolak model homo economicus, dan tidak berpegang teguh pada sebagaimana banyak ekonom konvensional tidak puas, model semacam ini. Ini berarti bahwa kekakuan teoritisi ekonomi neo-klasik tidak lagi populer di anatara ekonom-ekonom konvensional sendiri. Sudah disepakati bahwa ilmu ekonomi sebagai ilmu sosial tidak bisa dipisahkan, baik dari cabang-cabang kajian sosial, maupun ideologi dan nilai-nilai para pakarnya. Jadi, perlu ditegaskan bahwa selalu ada derajat pengaruh ideologis yang mungkin bisa ditoleransi dan dipertanggungjawabkan oleh pembaca dan para teoritisi. Pentingnya pendekatan holistik ilmu ekonomi berasal dari Barat jauh sebelum ekonom-ekonom Islam mulai membicarakannya. Klaim ekonom-ekonom Islam untuk mengambil pendekatan holistik dalam ilmu ekonomi tidak muncul sebagai gagasan asli sebagaimana yang kita pikirkan. ${ }^{26}$

\section{Kesimpulan}

Dari pembahasan di atas, penulis dapat memberikan beberapa kesimpulan. Pertama, tugas untuk menguraikan sistem ekonomi Islam terdiri dari dua bagian. Pertama menemukan teori komponen sistem ekonomi dan hubungan internalnya. Kedua, menyelidiki validitas ekonomi dan daya terap sistem tersebut. Secara esensial, pendekatan yang digunakan untuk menemukan sistem ekonomi Islam sama dengan pendekatan yang digunakan untuk menemukan teori dan aturan umum fikih. Dalam merumuskan teori-teori dan aturan umum fikih, para fuqaha >' harus menyelidiki semua teks-teks al-Quran dan Sunnah. Beberapa teks mungkin secara langsung bisa diambil dari teks-teks itu sendiri. Metodologi menarik sistem ekonomi Islam dari sumber dasar Islam sama dengan metodologi mengembangkan aturan dan teoti umum fikih. Memanfaatkan sepenuhnya teks-teks al-Quran dan Sunnah untuk menarik "bentuk" umum atau pilar dasar sistem ekonomi Islam dan menyesuaikan kasus individual dengan pilar-pilar ini, sementara pada saat yang sama, mengambil warisan fikih sebagai alat yang berguna untuk memahami teks-teks tersebut.

Kedua, perlunya kajian sejarah. Ekonomi sebagai salah satu ilmu sosial perlu mengembangkan jalan ke arah sejarah untuk menggali pengalamannya dan menentukan arah kehidupan ekonomi jangka panjang. Kajian historis dalam ilmu ekonomi paling tidak mencakup dua aspek yang sangat penting, yaitu sejarah pemikiran ekonomi dan sejarah kesatuan ekonomi. Namun, perlu kiranya diwaspadai ketika kita mengkaji aspek historis Islam ini, sebagaimana yang dicatat oleh Kahf. Pertama, bahaya kekeliruan mencocokkan teori dengan aplikasinya. Kedua, bahaya membatasi teori dengan sejarahnya.

Ketiga, ekonom-ekonom Islam harus merevisi teori ekonomi konvensional untuk mengenali dan memisahkan postulat-postulat yang bias. Dengan kata lain, memperbaiki teoriteori yang penuh dengan pandangan dogmatis, doktrinal, dan moral para ahlinya dan lingkungan sekitar. Meskipun hukum-hukum ekonomi itu bersifat universal, namun hukumhukum tersebut merupakan proses yang dipengaruhi oleh gagasan dan nilai-nilai para peneliti dan perilaku sosial yang ada dan etika moral dari entitas sosial yang perilakunya ditinjau oleh para ahli disiplin tersebut.

\footnotetext{
${ }^{26}$ Ibid.
} 


\section{Daftar Rujukan}

Anas, Irham Fahreza. "Analisis Komparatif Pemikiran Abdul Mannan dan Monzer Kahf dalam Konsumsi Islam”. Skripsi--UIN Syarif Hidayatullah, Jakarta, 2008.

Aravik, Havis. Sejarah Pemikiran Ekonomi Islam Kontemporer. Jakarta: Kencana, 2017.

Furqani, Hafas. "Signifikansi Kajian Metodologi dalam Pengembangan Body of Knowledge Ekonomi Islam”. EQUILIBRIUM (Jurnal Ekonomi Syariah). Vol. 4, No. 1, Juni, 2016.

Hakim, Isyhar Malija. "Analisis Komparatif Pemikiran Fahim Khan dan Monzer Kahf Tentang Perilaku Konsumen”. Skripsi--UIN Walisongo, Semarang, 2015.

Haneef, Mohamed Aslam and Hafas Furqani. "Methodologi of Islamic economics: Overview of Present State and Future Direction". International Journal of Economics, Management \& Accounting. Vol. 19, No. 1, 2011.

Pemikiran Ekonomi Islam Kontemporer: Analisis Komparatif Terpilih, terj. Suherman Rosyidi. Jakarta: PT. Raja Grafindo Persada, 2010.

Kahf, Monzer. "Islamic Economics: Notes on Definitionand Methodology" dalam Sercan Karadoğan (ed), Islamic Economics: On Definition and Methodology. Istambul: Alioğlu Printing, 2014.

. "Islamic Economics: Notes on Definition and Methodology". Review of Islamic Economics. No. 13, 2003.

"Islamic Economics and Its Methodology". Dalam Syed Omar Syed Agil dan Aidit Ghazali (ed). Reading in the Concept and Methodology of Islamic Economics. Malaysia: CERT Publication, 2007.

Rahardjo, M. Dawam. "Metodologi Ekonomi Islam”. JEP. Vol. 3, No. 1, 1998.

Sawit, M. Husein. "Metodologi Penelitian Ekonomi Islam: Perlukah Berbeda?”. JEP. Vol. 3, No. 1, 1998.

Maulidizen, Ahmad. "Methodology of Islamic economics: an Analysis Comparison". Islamiconomic: Jurnal Ekonomi Islam. Vol. 8, No. 1, Januari-Juni, 2017.

Mughits, Abdul. "Pengantar Epistemologi dan Metodologi Ilmu Ekonomi Islam". Tim Penulis FSEI (ed). Filsafat Ekonomi Islam. Yogyakarta: Forum Studi Ekonomi Islam, 2008. 